\title{
Measurement of rates of surface lowering of limestone in the southern Pennines: an example in the Wye catchment, Derbyshire, UK.
}

\author{
Banks, V.J., ${ }^{1,2^{*}}$ and Jones, P.F. ${ }^{2}$ \\ ${ }^{1}$ British Geological Survey, Kingsley Dunham Centre, Nicker Hill, Keyworth, Nottingham NG12 5GG \\ ${ }^{2}$ University of Derby, Geographical, Earth and Environmental Sciences, Kedleston Road, Derby, DE22 1GB \\ * Corresponding author. E-mail address: vbanks@bgs.ac.uk
}

\begin{abstract}
Measurement of the differential denudation between chert and limestone in a Carboniferous limestone sequence that was cut during excavations for a railway tunnel (in 1865) has provided a means of assessing limestone dissolution rates in a valley side setting in the southern Pennines over the last 150 years. Dissolution rates of $0.035 \mathrm{~mm} /$ annum have been determined. This rate falls within the range of previously determined limestone dissolution rates in the UK, which have been described in the context of different methods of measurement and the difference in denudations rates over time.
\end{abstract}

\section{Introduction}

Monitoring rates of weathering and erosion provides data that contribute both to the interpretation of landscape evolution (including speleogenesis) and understanding of the durability of building stones (Pope et al., 2002; Trudgill and Viles, 1998). In the case of limestone such studies have a long standing, but ongoing place in karst literature (Goodchild, 1875, Sweeting, 1972, Trudgill, 1983, Ford and Williams, 2007). Developments in the potential to calculate exposure ages and erosion rates, e.g. Balco and Shuster (2009) have rejuvenated interest in rates of surface lowering, e.g. Wilson et al. (2012). The aim of this paper is to review the different techniques that are available for the measurement of rates of dissolutional lowering of limestone and then describe a technique and results from a trial locality in the Peak District, Derbyshire in the context of other published rates of dissolution. Whilst the research area is inevitably site-specific, it is considered that the method of measurement deployed in this study can be applied to other karst environments in a range of geographical settings. The research area was centred on National Grid Reference SK 1715072428 (Figure 1A) on the southern valley side of the River Wye, Derbyshire, U.K, at an elevation of approximately $240 \mathrm{~m} \mathrm{OD}$ where the bedrock comprises Carboniferous limestones of the Monsal Dale Limestone Formation. These Dinantian rocks comprise shallow water, carbonate shelf limestones, which were laid down during the Carboniferous when Britain was closer to the equator than it is today.

The Brigantian stage Monsal Dale Limestone Formation comprises an upper pale limestone facies and a lower dark limestone facies. It is the latter that underlies the research area with a dip of approximately 5 degrees to the south in the vicinity of the research area (BGS, 1978). The dark facies have been shown (Walkden, 1987) to be cyclic (regressive sequences), albeit with less evidence for emergence than observed in the pale facies (Aitkenhead et al., 1985). These limestones largely comprise biosparites and bioclastic calcisiltites with rarer biomicrites and range in colour from mottled shades of grey to true dark grey (Cox and Bridge, 1977; Gawthorpe et al., 1989). Aitkenhead et al. $(1985$, p26) note that chert is common, but not universally present and Ford (2002) suggests that the chert, which occurs as nodules, is the product of the alkali solution of silica derived from siliceous skeletons and re-precipitation in zones of acid conditions. The depositional environment has been interpreted by Aitkenhead et al. (1985) as one of a shallow carbonate shelf subject to interplay between eustatic and tectonic controls on sedimentation. The evidence favours eustatic changes, of a type that could have been brought about by the fluctuations in the ice mass covering Gondwanaland, superimposed 
upon the tectonic control. The limestone sequence was subject to late Carboniferous mineralization of the Mississippi Valley type such that many of principal faults and joints in the vicinity of the research area contain lead-zinc mineralization. Aerial photographs indicate that the closest of the abandoned mine workings are approximately $350 \mathrm{~m}$ to the east. A former calcite spar mine (Monsaldale Spar Mine, or Putty Hill Mine, worked between 1879 and 1931; Rieuwerts, 2008) is situated approximately $800 \mathrm{~m}$ to the south-west.
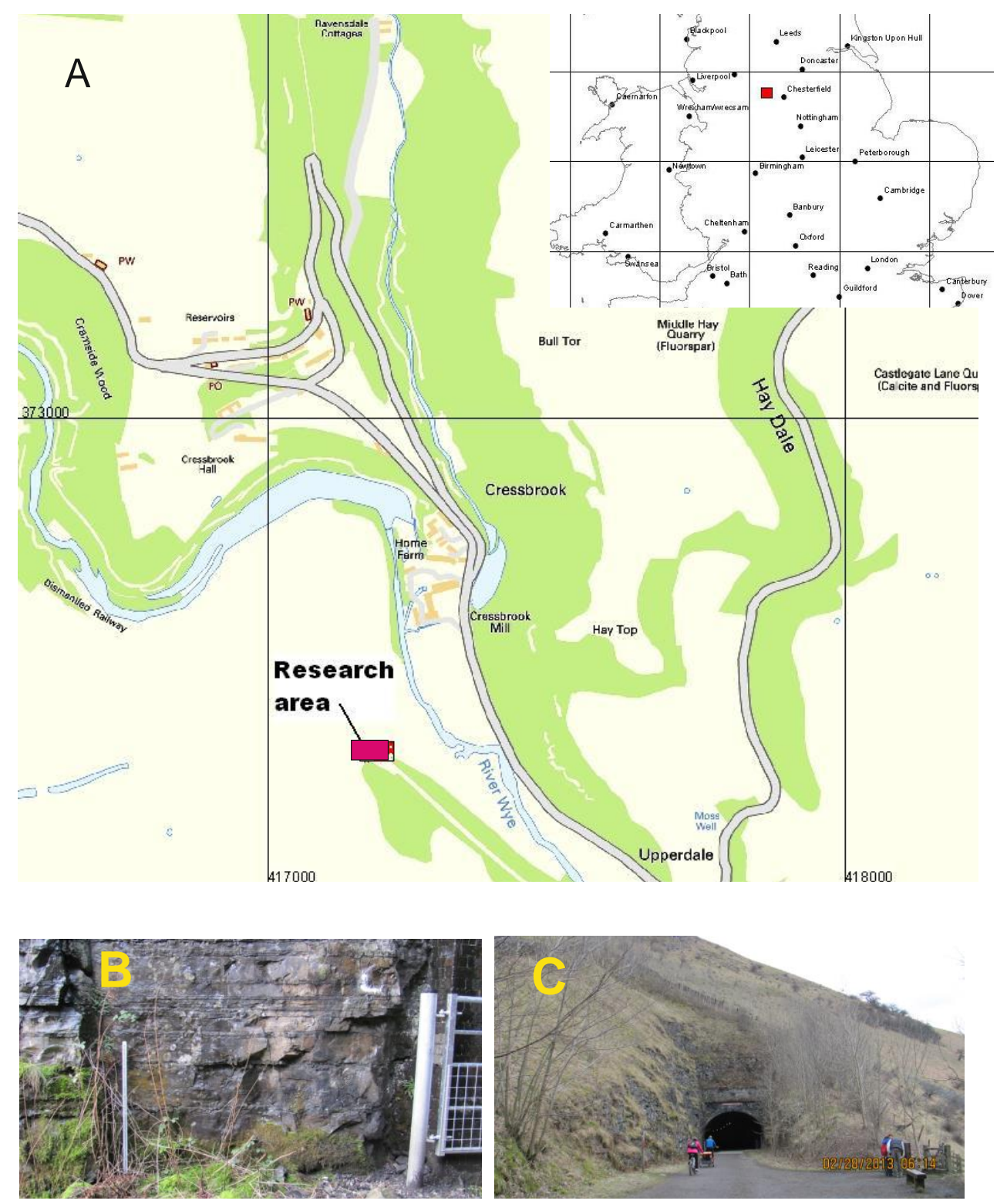

Figure 1. A: Location of the research area; B: Interbedded limestone and chert, metre rule for scale, and C: North-west facing view of the survey site [note $28^{\circ}$ slope angle and higher density of medium mature trees on the north-east side of the cutting (right)].

A key consideration in calculations of dissolutional lowering is that dissolution results in a loss of solid and a commensurate gain in dissolved material in the solvent, such that authors, including Garrels and Mackenzie (1971), Hem (1985) and Meybeck (1987), have characterised groundwater and river water chemistry in accordance with the bedrock source. In the case of rivers, the water chemistry can be taken as an indicator of dissolutional erosion rates. Studies of this type can be used to provide an indication of relative rock resistance to dissolutional erosion rates, for example Meybeck (1987), working in France, established lithology erosion rates relative to granite (Table 1 ) 
Table 1: Relative dissolution rates as indicated by river chemistry in French catchments (Meybeck, 1987).

\begin{tabular}{lc}
\hline Rock Type & $\begin{array}{c}\text { Erosion rate (mass of major ions per unit time) } \\
\text { Relative to granite }\end{array}$ \\
\hline Granite & 1.0 \\
\hline Gneiss and mica schist & 1.0 \\
\hline Gabbro & 1.3 \\
\hline Sandstone & 1.3 \\
\hline Volcanic rocks & 1.5 \\
\hline Shales & 2.5 \\
\hline Serpentine and amphibolite & 5 \\
\hline Carbonate rocks & 12 \\
\hline Gypsum & 40 \\
\hline Rock Salt & 80
\end{tabular}

\section{Techniques available for measuring rates of limestone dissolution.}

Limestone dissolution has been studied extensively in the context of karst geomorphology (Appelo and Postma, 2005; Ford and Williams, 1989 and 2007; Gunn, 1986; Herman and White, 1985, and Trudgill, 1985a; Table 2).

Table 2: Physical, chemical and biological influences on limestone dissolution.

\begin{tabular}{|c|c|c|}
\hline Chemical Factor & Influence & Reference \\
\hline Controlling chemical equations & & $\begin{array}{l}\text { Appelo and Postma } \\
\text { (2005) }\end{array}$ \\
\hline $\mathrm{CO}_{2}(\mathrm{~g}) \leftrightarrow \mathrm{CO}_{2}(\mathrm{aq})$ & $\begin{array}{l}\text { Absorption of carbon dioxide in water; slow rate } \\
\text { limiting reaction }\end{array}$ & $\begin{array}{l}\text { Kaufman and Dreybrodt } \\
\text { (2007) }\end{array}$ \\
\hline $\mathrm{CO}_{2}(\mathrm{aq})+\mathrm{H}_{2} \mathrm{O} \leftrightarrow \mathrm{H}_{2} \mathrm{CO}_{3}$ & Formation of carbonic acid & \\
\hline $\mathrm{H}_{2} \mathrm{CO}_{3} \leftrightarrow \mathrm{H}^{+}+\mathrm{HCO}_{3}^{-}$ & first dissociation of carbonic acid & \\
\hline $\mathrm{HCO}_{3}^{-} \leftrightarrow \mathrm{H}^{+}+\mathrm{CO}_{3}{ }^{2-}$ & second dissociation & \\
\hline $\begin{array}{l}\text { Chemical composition of } \\
\text { limestone }\end{array}$ & $\begin{array}{l}\text { e.g. dolomite dissolution slower than that of } \\
\text { calcite }\end{array}$ & $\begin{array}{l}\text { Herman and White } \\
\text { (1985) }\end{array}$ \\
\hline $\begin{array}{l}\text { Metals may inhibit calcium } \\
\text { bicarbonate formation, in } \\
\text { decreasing order of } \\
\text { effectiveness: lead, lanthanum, } \\
\text { yttrium, scandium, cadmium, } \\
\text { copper, gold, zinc, germanium } \\
\text { and manganese }\end{array}$ & $\begin{array}{l}\text { A consequence of the increased surface } \\
\text { concentration of carbonate ions and increasingly } \\
\text { effective as equilibrium is reached. }\end{array}$ & Terjesen et al. (1961) \\
\hline Physical Factor & Influence & Reference \\
\hline $\begin{array}{l}\text { Rock properties: density, grain } \\
\text { size and structure. }\end{array}$ & $\begin{array}{l}\text { The distribution of porosity and permeability; } \\
\text { surface area, and distribution of recharge }\end{array}$ & $\begin{array}{l}\text { Drew (1985), Ford and } \\
\text { Cullingford (1976) and } \\
\text { Sweeting (1972) }\end{array}$ \\
\hline
\end{tabular}




\begin{tabular}{|l|l|l|}
\hline Impurities & $\begin{array}{l}\text { Commonly a focal point for dissolution, e.g. silica } \\
\text { and clay minerals are less soluble and occlude } \\
\text { permeability }\end{array}$ & \\
\hline Biological Factor & \multicolumn{1}{|c|}{ Reference } \\
\hline $\begin{array}{l}\text { Plant roots, bacteria, lichen and } \\
\text { fungi }\end{array}$ & Direct attack and chelation & Trudgill (1985b) \\
\hline $\begin{array}{l}\text { Organic acids produced during } \\
\text { the decay of organic matter } \\
\text { and from tree bark leachates }\end{array}$ & Production of hydrogen and hydrolysis & Trudgill (1985b) \\
\hline Fauna & $\begin{array}{l}\text { Gastropod mucus } \\
\text { Physical disturbance resulting in preconditioning } \\
\text { of rock }\end{array}$ & \\
\hline Anthropogenic activity &
\end{tabular}

Table 3: Range of techniques available for determining rates of dissolutional lowering in limestones.

\begin{tabular}{|c|c|}
\hline Direct Technique & References \\
\hline Micro-erosion meter & $\begin{array}{l}\text { High and Hanna, 1970; Lauritzen, 1990; Trudgill, 1985; Trudgill, } \\
1983\end{array}$ \\
\hline Erosion pins & Trudgill, 1983 \\
\hline Differential erosion & Lauritzen, 1990; Trudgill, 1983 \\
\hline Measurement of pedestals & Lauritzen, 1990; Trudgill, 1983; Goldie, 2006, Parry 2007 \\
\hline Measurement of fossils heights on dated surfaces & Goodchild, 1890. \\
\hline Measurement of rate of loss of exposed glacial striations & Goodchild, 1890. \\
\hline Indirect Technique & References \\
\hline Gravestones and monuments & $\begin{array}{l}\text { Goodchild, 1890; Sweeting, 1972, Pope et al., 2002; Trudgill, 1985; } \\
\text { Trudgill, } 1983\end{array}$ \\
\hline Weight loss of tablets & $\begin{array}{l}\text { Trudgill, 1985; Trudgill, 1983;Martinez and White, 1999; Mcllroy de } \\
\text { la Rosa et al., } 2013\end{array}$ \\
\hline $\begin{array}{l}\text { Solute concentration/ mass balance of calcium and } \\
\text { magnesium by titration }\end{array}$ & Lauritzen, 1990; Pitty, 1966; Trudgill, 1985 \\
\hline Empirical techniques, e.g. Corbel’s equation & Ford and Williams, 2007; Sweeting, 1972 \\
\hline Laboratory experiments & $\begin{array}{l}\text { Herman and White, 1985; Trudgill and Viles, 1998; Mcllroy de la } \\
\text { Rosa et al., } 2012\end{array}$ \\
\hline Geochemical modelling & Corbel, 1960; Fleurant et al., 2008; White, 1984 \\
\hline
\end{tabular}

Rates of dissolutional lowering can be determined through either direct physical measurements or indirect techniques (Table 3). Indirect techniques are based on the assumption that the solute content of springs or seepages results from the dissolutional lowering of the limestone in accordance with the chemical equations detailed in Table 2. Direct measurement of dissolutional lowering provides the most reliable results, however given the relatively low solubility of limestone, the monitoring requires long time periods (years) to collect sufficient data for conversion into rates of dissolutional lowering. The favoured technique for direct measurement is the micro-erosion meter that measures the height of a rock surface relative to a reference point (Trudgill, 1983). It consists of a micrometer probe attached to a dial gauge, which is mounted on a tripod. The tripod legs are designed to sit on studs that are mounted into the rock and provide a reference point against which measurements are made. The studs and micrometer arrangement all need to be fully protected between measurements to ensure that precision of the instrumentation is maintained. Erosion pins provide another technique for direct measurement. The pins, which comprise metal rods, are driven into the rocks and form reference points against which dissolution can be monitored. This technique also requires long (years) 
monitoring time scales (Trudgill, 1983). There are a number of alternative direct measurement techniques that provide long-term mean rates of erosion, including differential weathering, height of pedestals and measurement from dated surfaces. Differential weathering may result from the different solubilities of rock types, e.g. quartz and limestone, which leaves one rock type proud of the other. Lauritzen (1990) used this property to estimate long-term erosion rates in Svartisen, North Norway, where a glacially eroded surface had subsequently weathered such that quartz was standing proud of the limestone. In using this method, Lauritzen (1990) took the greatest differential as being representative of the extent of surface lowering since the surface was glaciated. Similarly, when large glacial erratics are deposited on hard rock surfaces, they can protect the underlying surface from subsequent weathering such that the surrounding rock is eroded and the surrounding surface is lowered leaving the rock beneath the erratic to form a pedestal. The height of the pedestal can be used to determine a rate of erosion since the time of deposition of the erratic (Trudgill, 1983). The caveats associated with date constrained geological surfaces include the uncertainty with respect to the period of time that has elapsed since the surface was exposed, the uncertainty regarding the evenness of dissolutional lowering during the elapsed time period and uncertainty regarding the assumed eveness of the surface upon which a pedestal has formed. A further consideration is the difficulty in measuring pedestal height, because of the irregular surface and irregular pedestal height White (2000). The uncertainty of the elapsed time interval can be reduced through cosmogenic techniques for dating the exposure of limestone surfaces, e.g. Wilson et al. (2012).

The time-scales involved in monitoring dissolutional lowering or uncertainties associated with determining mean dissolution rates from longer periods of erosion are such that indirect methods (Table 3) of rate determination can be attractive. Of these methods, among the first deployed, were the wasting of tombstones (Goodchild, 1875 and 1890), building stones (Goodchild, 1890) and road surfaces (Goodchild, 1890). If the construction date is known then surface alteration of the building stones will give a good indication of the rates of weathering and erosion (Pope et al., 2002). Goodchild $(1875 ; 1890)$ assessed the extent of surface alteration from the change in shape of the building stones or the determination of the amount of protrusion of fossils on an eroded limestone surface. This technique can be difficult as it often requires subjective visual observations (Trudgill, 1983). Furthermore, building stones and gravestones are commonly derived from a specific rock member or formation because of the uniqueness of the benefits of the rock properties to the application, which may render them unrepresentative of the surrounding rocks in the landscape. Dressed stone will also have been subject to stress during its working, which may affect its propensity for weathering (Fookes et al., 1988). Tablet mass loss determinations provide another indirect technique for determining rates of dissolutional lowering. The method can be used in a range of settings and relies on the accurate measurement of the initial density and volume of 2.5 to $3.5 \mathrm{~mm}$ thick tablets, which are cut from $40 \mathrm{~mm}$ diameter cores to produce a relatively large surface area. The tablets can be placed in streams or buried within the soil profile (Crabtree and Trudgill, 1985) and left for months or years, then retrieved, cleaned and re-weighed. From the loss in mass an equivalent volume can be calculated from the density, which in turn can be used to determine the equivalent surface lowering. It is implicit in the method of calculation that the density of the tablet is even throughout its volume, which is unlikely. Laboratory experiments can also be undertaken using tablets, e.g. Mcllroy de la Rosa et al. (2013). One advantage of tablets is that, by using a standard limestone, direct comparisons can be made of the response to different climates or depths. Alternatively, catchment-specific limestones can be used to generate the tablets.

Dissolutional denudation can be determined from the product of discharge and solute load, e.g. Pitty (1966), but in order to convert this to rates of surface lowering it is necessary to know the density of the limestone, the catchment area and the proportion of the load that is derived from the surface. This assessment can be difficult in karst environments, where much of the dissolutional activity can be focused on carbonate in the soil profile (Trudgill, 1985a) or within the rock mass, where there is commonly a focus on discontinuities. Whilst karstification can be considered as a process that is independent of denudational lowering (Ford and Williams, 2007) some karst specialists include all rock mass dissolutional activity in their assessment of denudation rates 
on the assumption that in the long term dissolution at depth is propagated as surface denudation (Gabrovsek, 2007). Both karstification and surface lowering will be susceptible to the variation in the distribution of carbon dioxide. Atmospheric $\mathrm{PCO}_{2}$ is $10^{-3.5}$ atm., whereas the $\mathrm{PCO}_{2}$ values for groundwater are typically much higher (up to approximately 6\%, Ford and Williams, 2007), as a consequence of the addition of biologically (plant respiration) derived carbon dioxide (Atkinson, 1977). The variation in the production of carbon dioxide is primarily related to the temperature, moisture content and amount of organic matter in the soil and therefore it reflects climate and seasonality (Ford and Williams, 2007; Kehew, 2001). Whilst the theoretical assumption is that all of the $\mathrm{CO}_{2}$ occurs as carbonic acid, in practice reaction rates are such that most of the $\mathrm{CO}_{2}$ is present in its dissolved form. Both ground surface and underground dissolution are not uniform processes. Dissolution is greatest: at points of convergence where mixing corrosion can occur; in zones of more intense biological activity; where soil moisture is high, and in areas with a sunny aspect (Ford and Williams, 2007). These different conceptual models will be reflected in the reporting of rates of dissolutional lowering from water chemistry analyses.

A number of geochemical modelling techniques have been applied to the assessment of surface lowering. One of the earliest was that of Corbel (1960). Corbel's equation is:

$4 \mathrm{ET}(\mathrm{N}) / 1000=\mathrm{X}$, where

$E=$ run-off (decimetres), $T=$ average $\mathrm{CaCO}_{3}$ content $(\mathrm{ppm}), \mathrm{X}=$ value of the limestone in solution $\mathrm{mm} / 1000$ years, and $1 / \mathrm{N}=$ proportion of limestone in the basin (Sweeting, 1972). The weak evidence base and difficulty in applying Corbel's work to different climatic regimes has been described in the literature, e.g. Smith and Atkinson (1976) and Trudgill (2008).

This work was reviewed and updated (Sweeting, 1972; White, 2000) with modification to the equation to allow for variability in the density of the limestone (Corbel assumed a density of 2.5) and total hardness. Corbel's modified equation is: $E T N / 10 D=X$, where $D$ is the density of the limestone or dolomite and $T$ is the mean total hardness.

Denudation rates can also be modelled in terms of effective rainfall, partial pressure of carbon dioxide and temperature (White, 1984) and using integrated landscape models, e.g. CHILD (Channel-Hill slope Integrated Landscape Development; Fleurant et al., 2008).

\section{Differential weathering assessment used in this study.}

The method that is described below comprises the measurement of differential weathering on dated surfaces. The dated surfaces comprise the cut faces of a former railway cutting in the Monsal Dale Limestone Formation (described above), which are immediately adjacent to the portal at the south-eastern end of the Cressbrook Tunnel (Figure 1A; SK 17159 72439). This was once a section of the Manchester, Buxton, Matlock and Midland Junction Railway. The southern section (Ambergate to Rowsley) was opened in 1849 (Hey, 2008). After the railway was taken over by the Midland Railway Company and the Duke of Rutland had agreed to a route that took the railway in tunnel past Haddon Hall, the Rowsley to Buxton section was opened in 1863, albeit that the date engraved above the tunnel portal is 1883 . The railway was closed in 1959, but the surfaces were made accessible as a consequence of the recent (2011) opening of the tunnel sections of the Monsal Dale Trail, which is a pedestrian and cycle route that follows the line of the disused railway. 

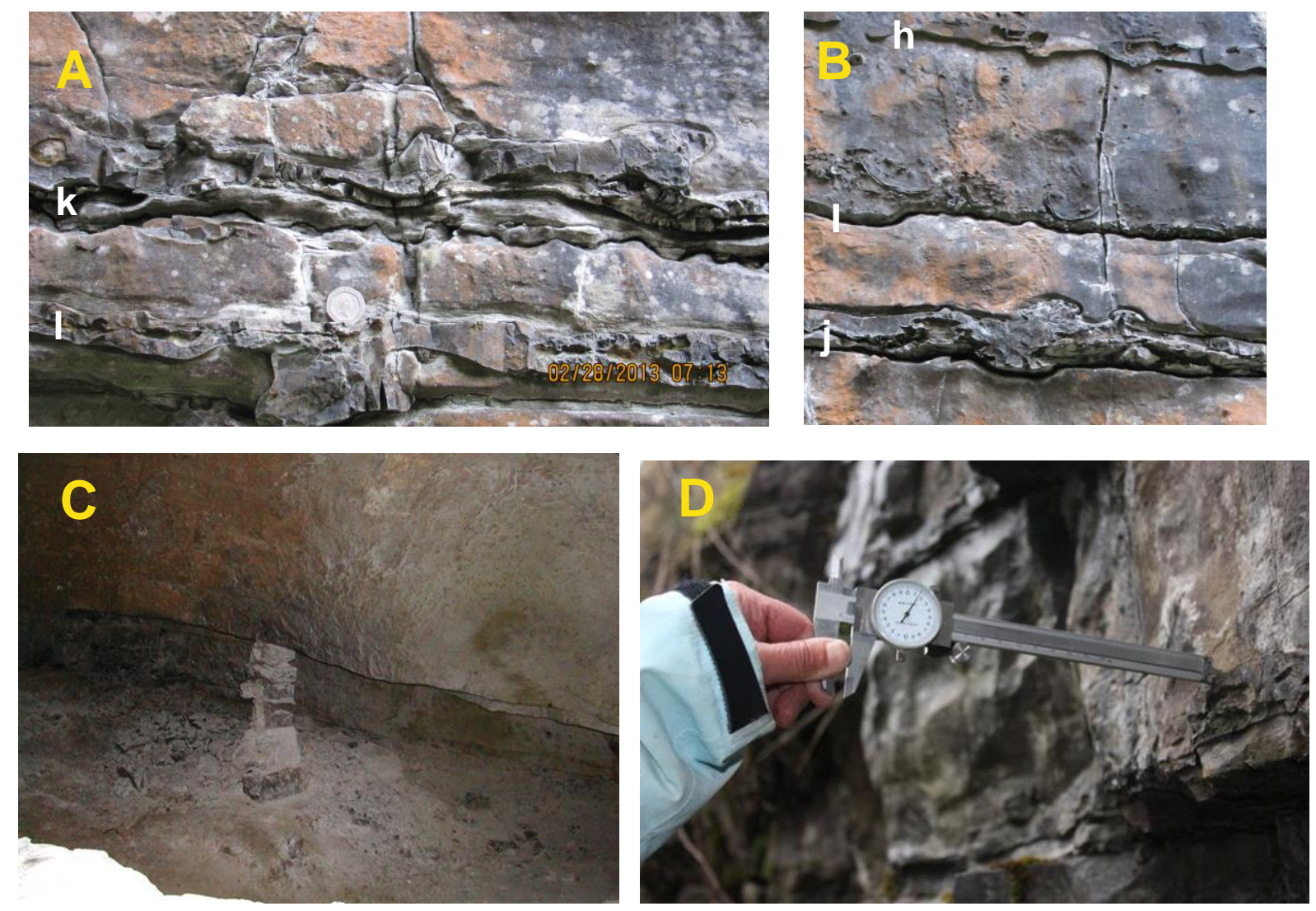

Figure 2. A: nodular chert above stylolite. Note frost plucking on the outside edge of some of the nodules. (20 pence coin for scale; letters identify chert bands); B: north-east side of cutting (letters identify chert bands) with silicified brachipods in layer i with sylolite below; C: chert in Pretoria Mine, Bakewell. Holing bed $(0.90 \mathrm{~m})$ spanned by supporting blocks, and D: use of vernier callipers to measure relative lowering of limestone above the chert band.

Cut rock surfaces immediately adjacent to the south-eastern tunnel portal comprise interbedded limestones and tabular, dark grey coloured chert of the Monsal Dale Limestone Formation. The continuity of the beds of chert is striking (Figure 1B) and can be seen to extend across the cutting as well as along it. The valley side slopes approximately $28^{\circ}$ to the north and is largely grass covered with a number of isolated trees. Ledges within the cutting, which are more numerous on the north-east side, are grass and moss covered. On the north-east side of the cutting there are significantly more medium mature trees (ash with occasional sycamore and beech) than on the south-west side (Figure 1C). Ferns and bracken are more common on the south-west side of the cutting. The chert beds vary in thickness between a few millimetres and $10 \mathrm{~cm}$. Some are associated with stylolites (Figure $2 \mathrm{~A}$ ) and, where this is the case, the chert commonly takes a nodular form (Figure 2A). Not all of the limestone blocks have been cut smoothly with localised evidence of subsequent jointing and physical (possibly frost) weathering in the form of isolated mounds of rock fall debris. The joints commonly pass through the cherts, but are often apparently not so well developed, because they tend to be dissolutionally enlarged in the limestone. Locally, some bands of the chert are more intensely fractured with fine fractures that are generally perpendicular to the bedding, which reflects the brittle nature of this material. A number of the nodular cherts also exhibit fine fracture patterns that are perpendicular to the nodule faces (Figure 2A). Over much of the rock face, the chert stands proud of the limestone (Figure 2B). This differential weathering results from the contrasting resistance to dissolution of the inter-bedded cherts and limestone.

Cherts comprise micro- or crypto- crystalline silica, which can occur in nodular or tabular forms. A biogenic source is commonly postulated for chert in carbonates. Radiolaria dominate in the marine environment along with diatoms. In Palaeozoic sequences, particularly in deep basinal deposits, siliceous sponge spicules provide 
an adequate source of silica to form chert nodules Hesse (1988). However, Hesse (1989) noted that the source of pervasive to completely silicified layers is usually attributed to inorganic sources of silica, which can be either primary or secondary (replacive). A possible biogenic source was suggested for the Derbyshire cherts by Jessop (1931). Although siliceous spicules are common to these limestones, the distribution of chert is very variable. It becomes notably thicker (beds of up to $6 \mathrm{~m}$; Figure 2C, and Bowering and Flindall, 1998) in the area of Bakewell (approximately $6 \mathrm{~km}$ to the south-east of the research site), where it is associated with the presence of faults. The silica is largely replacive (Bowering and Flindall, 1998; Figure 2B), which results in variability in the calcium content of chert (Table 3). Silica is soluble in high $\mathrm{pH}$ and reducing conditions. Accordingly, it is plausible that the chert is either derived from an alkali mineral solution (possibly associated with clay tranformations) or from a hydrocarbon rich fluid (Hollis and Walkden, 1996) that it is mobilised along fractures (bedding and jointing) by seismic pumping (Colman,et al., 1989), precipitating where it meets an oxidation front. Further research is required to confirm this. Concentrations of lead, zinc, barium and chromium determined in the chert from Pretoria Mine (Table 4) were lower than background concentrations in the limestone (Harrison and Adlam, 1985) and are more elevated where calcium to silica ratios are higher, indicating that the silica is not directly associated with subsequent mineralization. However, as noted by Orme and Ford (1970) of the chert at Ashford, early phases of chert are cross cut by subsequent phases of both quartz and mineralization, indicating that the majority of the chert formed very early in the diagenesis of the limestone platform.

Changes in relief across the rock surface that are attributable to the relative difference in the erosion rates of carbonate and silica (chert, Table 1) form the basis of the hypothesis that the relatively low rate of dissolution of silica renders it suitable as a baseline against which to measure the limestone dissolution since the cutting was excavated. Accordingly, a systematic survey of the height difference between the surface of the chert and that of the limestone was undertaken. The measurements were made using vernier calipers (Figure 2D) at $0.10 \mathrm{~m}$ intervals along each of the chert bands on both sides of the portal. At each measurement point, readings were taken immediately above and below (upper and lower) the chert band. Each of the chert bands was designated a letter to formalise the correlation that was visually evident between the north-east and south-west sides of the cutting. The following assumptions were made in this survey: that the surfaces were flush when cut; that the differential weathering is attributable to dissolutional lowering of the limestone, that the chert, which is very brittle, has not been subject to physical weathering and that there has been no subsequent anthropogenic modification of the cut face. A number of criteria were applied to the monitoring exercise in accordance with the following: a) Measurements were not made on vegetated surfaces. b) Measurements were made to limestone surfaces rather than into the recessive cavities that result from bedrock dissolution along inception horizons, e.g. layer i in Figure 2B. c) Measurements were not taken where the limestone was clearly jointed and it was considered that the jointing might have a stronger influence on the measurements than dissolution. 
Table 4: XRF results from Pretoria Mine, Bakewell. All concentrations $\mu \mathrm{g} / \mathrm{kg}$, analyses from Halpin (2004).

\begin{tabular}{|c|c|c|c|c|c|c|}
\hline Sample & 01 & 02 & 03 & 04 & 05 & 06 \\
\hline $\mathrm{Ca}$ & 56640 & 449000 & 59030 & 429100 & 582900 & 285500 \\
\hline $\mathrm{Ba}$ & 72 & 64.1 & 65.9 & 250.1 & 114.1 & $<11$ \\
\hline $\mathrm{Al}$ & $<500$ & 13270 & $<500$ & 4770 & 83900 & 114200 \\
\hline $\mathrm{Sr}$ & 21.8 & 369.3 & 19.2 & 445.4 & 325.5 & 222.8 \\
\hline $\mathrm{Mn}$ & 193.5 & 883 & 146.9 & 2485 & 647 & 301 \\
\hline $\mathrm{Pb}$ & 8.9 & 13.6 & 3.6 & 86.7 & 5.7 & 12.8 \\
\hline $\mathrm{Zn}$ & 51.6 & 99.9 & 42.3 & 377.4 & 83.5 & 74.1 \\
\hline Si & 953800 & 553800 & 956100 & 572300 & 114300 & 232500 \\
\hline 1 & 10.4 & $<4.5$ & $<4.4$ & $<4.1$ & $<5$ & $<4.3$ \\
\hline \multicolumn{7}{|c|}{$\begin{array}{l}\text { Sample } \\
\text { descriptions: }\end{array}$} \\
\hline 01 & \multicolumn{6}{|c|}{ Fallen sample, from the floor of the main incline. Very fine-grained banded grey, pale grey and pale brown, silicified limestone. } \\
\hline 02 & \multicolumn{6}{|c|}{$1.2 \mathrm{~m}$ above track level; sample of grey amorphous silicified limestone. } \\
\hline 03 & \multicolumn{6}{|c|}{$\begin{array}{l}1.5 \mathrm{~m} \text { above track level; banded silicified limestone; upper } 3 \mathrm{~cm} \text { of fine (mm scale), locally irregular laminae identified by the } \\
\text { variation in pale brown with pale grey colouring; grading into } 2 \mathrm{~cm} \text { of dark grey silicified limestone, with fine laminae of darker } \\
\text { grey; underlying a distinct boundary comprising } 2 \mathrm{~cm} \text { band, almost white in colour, with sporadic large crystals of up to } 0.5 \mathrm{~cm} \\
\text { of calcite along the upper boundary; grading to a } 4 \mathrm{~cm} \text { band of paler grey, almost amorphous, silicified limestone. }\end{array}$} \\
\hline 04 & \multicolumn{6}{|c|}{$\begin{array}{l}1.60 \mathrm{~m} \text { above track level; banded silicified limestone comprising fine, irregular, laminae identified by the variation in pale brown } \\
\text { and pale grey colouring. Laminae coincident with bedding. }\end{array}$} \\
\hline 05 & \multicolumn{6}{|c|}{$\begin{array}{l}1.95 \mathrm{~m} \text { above track level; pale grey with a pale brown }(1.5 \mathrm{~cm}) \text { band, silicified limestone. The paler brown band appears to be } \\
\text { less crystalline, with more iron - iron staining on the weathered surface of the sample. Both bands react more or less equally } \\
\text { with hydrochloric acid and as the acid reacts; dark flecks can be seen to be raised to the surface by the effervescing acid. }\end{array}$} \\
\hline 06 & \multicolumn{6}{|c|}{$\begin{array}{l}\text { Pale grey, dense silicified limestone, with poorly developed lamination visible to the naked eye as cream and pale brown colour } \\
\text { banding. }\end{array}$} \\
\hline
\end{tabular}

\section{Monitoring Results.}

A summary of the results has been tabulated (Table 5). In this table the depths to the limestone surface, relative to the adjacent chert beds have been recorded immediately above (upper) and below (lower) each of the beds of chert. Correlation between the mean upper and lower dissolution values for each of the beds on each side of the cutting is 0.209 , which increases to 0.49 when just the lower values are compared. The statistics defining the distribution curves (Figure $3 \mathrm{~A}$ ) were tabulated (Table 6). These show that the frequency curves for each side of the cutting are positively skewed and are asymmetrical. Both curves take a similar form. 
Table 5: Survey results (dissolution relative to chert bands A-W [mm]).

\begin{tabular}{|c|c|c|c|c|c|c|}
\hline $\begin{array}{l}\text { Chert } \\
\text { Layer }\end{array}$ & $\begin{array}{l}\text { Cutting (north-east) } \\
\text { Max }\end{array}$ & Min & Mean & $\begin{array}{l}\text { Cutting (south-west) } \\
\text { Max }\end{array}$ & Min & Mean \\
\hline a upper & 10.53 & 3.46 & 6.27 & 4.25 & 0.18 & 2.11 \\
\hline a lower & 23.38 & 7.42 & 14.00 & 22.22 & 0.92 & 10.10 \\
\hline b upper & 11.15 & 2.42 & 5.32 & 5.60 & 0.18 & 2.69 \\
\hline b lower & 26.88 & 3.52 & 10.12 & 20.14 & 1.34 & 8.02 \\
\hline c upper & 6.13 & 6.13 & 6.13 & 14.14 & 3.28 & 5.62 \\
\hline c lower & 7.14 & 7.14 & 7.14 & 41.76 & 2.97 & 14.83 \\
\hline d upper & 41.29 & 4.84 & 14.83 & 1.18 & 0.64 & 0.85 \\
\hline d lower & 10.98 & 5.06 & 7.32 & 2.44 & 1.42 & 1.77 \\
\hline e upper & 12.72 & 1.42 & 8.07 & 16.38 & 0 & 1.85 \\
\hline e lower & 11.26 & 4.18 & 6.84 & 11.84 & 0.48 & 3.74 \\
\hline f upper & & & & 12.88 & 0 & 5.02 \\
\hline f lower & & & & 7.64 & 0 & 4.02 \\
\hline g upper & 7.92 & 0 & 3.72 & 20.62 & 0.19 & 4.38 \\
\hline g lower & 11.87 & 0.63 & 5.58 & 20.26 & 0 & 5.06 \\
\hline h upper & 6.69 & 2.63 & 4.51 & 6.32 & 0 & 2.94 \\
\hline h lower & 7.00 & 2.66 & 4.87 & 112.56 & 1.16 & 20.15 \\
\hline i upper & 5.24 & 1.00 & 3.05 & 10.46 & 0.8 & 3.39 \\
\hline i lower & & & & 11.76 & 0.60 & 3.71 \\
\hline j upper & 10.17 & 3.84 & 6.16 & 6.72 & 0 & 2.74 \\
\hline j lower & 12.37 & 4.3 & 7.80 & 50.25 & 1.76 & 11.26 \\
\hline k upper & 8.01 & 0.24 & 4.08 & 9.82 & 0 & 3.79 \\
\hline k lower & 13.96 & 0.75 & 6.58 & 11.50 & 0.88 & 4.49 \\
\hline $\mathrm{m}$ upper & 8.47 & 0.98 & 4.83 & 6.52 & 0.36 & 2.76 \\
\hline $\mathrm{m}$ lower & 7.50 & 0.68 & 4.11 & 8.83 & 0.60 & 3.29 \\
\hline $\mathrm{n}$ upper & 6.92 & 0 & 3.38 & 6.41 & 0.35 & \\
\hline n lower & 12.74 & 1.02 & 5.14 & 10.48 & 0.14 & 3.34 \\
\hline o upper & 4.79 & 0.62 & 2.85 & 15.72 & 0.25 & 2.59 \\
\hline o lower & 23.67 & 1.24 & 5.64 & 13.18 & 0.16 & 3.16 \\
\hline p upper & 8.54 & 1.37 & 3.16 & 5.58 & 0 & 1.01 \\
\hline p lower & 8.78 & 1.78 & 3.94 & 8.34 & 0.13 & 3.94 \\
\hline q upper & 9.33 & 0.48 & 4.26 & 9.84 & 0.16 & 2.83 \\
\hline q lower & 12.46 & 1.58 & 5.94 & 6.70 & 0.30 & 2.65 \\
\hline r upper & 6.19 & 0.29 & 2.98 & 6.41 & 0.83 & 2.87 \\
\hline r lower & 5.30 & 0.41 & 3.09 & 7.58 & 0.31 & 3.19 \\
\hline s upper & 5.02 & 0.42 & 3.51 & 5.14 & 0.54 & 2.45 \\
\hline s lower & 8.52 & 0 & 4.45 & 6.94 & 0.60 & 3.04 \\
\hline t upper & 6.19 & 0.29 & 2.98 & 6.41 & 0.83 & 2.87 \\
\hline t lower & 5.3 & 0.41 & 3.09 & 7.58 & 0.31 & 3.19 \\
\hline u upper & 10.41 & 0.26 & 2.70 & 7.27 & 0.18 & 2.44 \\
\hline u lower & 15.03 & 0.98 & 4.78 & 10.20 & 1.08 & 4.12 \\
\hline v upper & 13.89 & 0.72 & 3.84 & 5.92 & 1.18 & 2.98 \\
\hline v lower & 22.83 & 0.91 & 8.33 & 6.93 & 0.75 & 2.98 \\
\hline w upper & 3.43 & 0.74 & 2.19 & 7.20 & 0 & 3.41 \\
\hline w lower & 2.97 & 1.47 & 2.40 & 12.48 & 0 & 5.36 \\
\hline
\end{tabular}

Table 6: Distribution of results.

\begin{tabular}{|l|l|l|}
\hline $\begin{array}{l}\text { Statistical } \\
\text { Parameter }\end{array}$ & $\begin{array}{l}\text { North-East } \\
\text { side of cutting }\end{array}$ & $\begin{array}{l}\text { South-West } \\
\text { side of cutting }\end{array}$ \\
\hline Mode & 4.00 & 2.52 \\
\hline Median & 4.125 & 3.16 \\
\hline Mean & 4.99 & 4.15 \\
\hline $\begin{array}{l}\text { Standard } \\
\text { Deviation }\end{array}$ & 4.01 & 6.45 \\
\hline
\end{tabular}



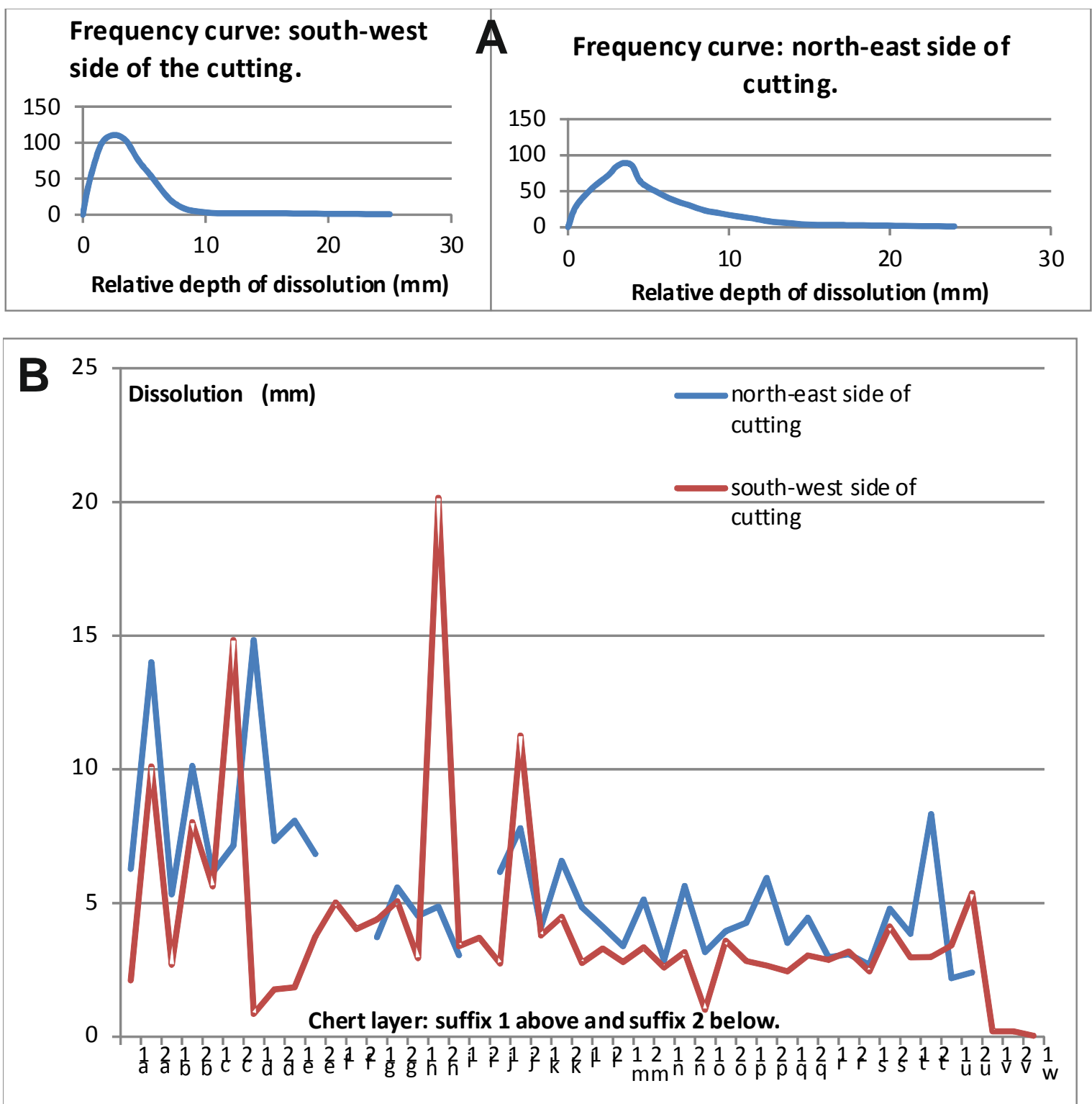

Figure 3. A: Distribution curves for the north-east $(n=46)$ and south-west $(n=42)$ sides of the cutting and $B$ : Plot of mean limestone recession relative to each chert layer (suffix 1 above; suffix 2 below the chert).

Mean depths of dissolution are lower on the south-western side of the cutting than on the north-east side, where there was a wider spread of results (as indicated by the standard deviation; Table 6). On both sides of the cutting there were higher rates of dissolution towards the top of the portal (dissolution measured against chert beds a to e). Examination of the lateral distribution of dissolution over each of the cutting faces indicates a more even distribution over the south-western side, whereas there is a concentration of high values 1 to $2 \mathrm{~m}$ from the portal on the north-eastern side. In the absence of any evidence of recent erosion of the chert beds mean chert protrusion amounts have been used to calculate dissolution rates. This differs from the approach taken by Lauritzen (1990) in Norway, where post glacial erosion of the quartz was suspected and dissolution rates were calculated from maximum quartz protrusion heights. The mean rate of dissolution has been calculated from the time elapsed since the cutting was driven (1863) as $0.035 \mathrm{~mm} / \mathrm{annum}$ or $35 \mathrm{~mm} / \mathrm{ka}$. 


\section{Analysis of the results.}

The River Wye is an easterly flowing tributary of the River Derwent. At Cressbrook the River flows at an elevation of approximately $190 \mathrm{~m} \mathrm{OD}$, approximately $50 \mathrm{~m}$ below the research site, where the river level is likely to be representative of the regional water table. However, there are stretches of the river (e.g. Monks Dale, Banks et al., 2009) where the water table is perched by the lavas during periods of low groundwater conditions. The results reported here are clearly indicative of surface dissolution in the vadose zone. In this area of the Peak District of Derbyshire, the hydrogeology is influenced by a number of geological and anthropogenic factors. The limestones are interbedded with basalts (lavas) that act as aquitards; clay wayboards (clay weathering product of volcanic dust) that also act as aquitards but may locally form horizontal flow paths, and layers of tabular chert or chert nodules that are relatively impermeable and impede groundwater flow, resulting in lateral flow along them. The limestones are faulted and mineralized. The faults and mineral veins can act as permeable or impermeable structures and locally compartmentalise groundwater bodies. Some limestones within the sequence have a greater propensity for dissolution than others, such that dissolutional activity (speleogenesis) tends to focus on inception horizons (Lowe, 2000) resulting in beddingparallel, anastomosing drainage that may feed a number of springs. Significant bedding-related guidance of groundwater is evident in the railway cutting (Figure 2B, layer i), where, following rain, inception horizon related groundwater seepages can be seen in both sides of the cutting. Whilst the regional hydraulic gradient is to the east (Downing et al., 1970) it is suspected that vadose zone flow follows the dip of the bedding to the south-south-east. Measurements of the differential wasting of the limestone were taken to the rock face, rather than into the inception horizons, such that the measurements presented here represent surface lowering rather than the sum karstification of the limestone. Similarly, no allowance has been made for the occurrence of localised coatings of tufa (precipitate of calcium carbonate).

Recharge to the Monsal Dale Limestone Formation is via both dispersed and concentrated autogenic recharge. Beneath the thin topsoil cover dispersed recharge is guided across the karstified bedrock surface to fracture networks; whereas concentrated recharge occurs via circular depressions (dolines) that are commonly focused on faults, mineral veins, dominant joints or specific geomorphological settings. The dolines tend to be larger on the Monsal Dale Limestone Formation (up to $800 \mathrm{~m}$ in diameter in the area of Calling Low, SK 18210 64746; Banks et al., 2009) than in the more heavily fractured limestones, e.g. Bee Low Limestone Formation and may be linked to cave systems, e.g. Lathkill Dale (Beck, 1980). A study of aerial photographs indicates the presence of abandoned mines to the west of the site, where there are also a number of former borrow pits, presumed to have been exploited for building stone. Also evident from the study of aerial photographs, recharge in the vicinity of the research area is predominantly dispersed with a potential for concentrated recharge associated with the nearby mine workings and small limestone borrow pit areas. The recharge process is important to both the internal karstification and the surface dissolution of limestone; because where potentially infiltrating water is impeded the increased residence time of the water facilitates more dissolution. This evidence suggests that rates of surface dissolution determined from the tunnel cuttings are likely to better represent the dissolutional activity of areas of dispersed recharge.

Spatial variability in soil carbon dioxide arises from variations in: biological activity, soil thickness, soil moisture and aspect (Ford and Williams, 2007). These are not independent variables. Evidence from the results presented here also points to the significance of the relationship between dissolution, aspect and vegetation type. Even though vegetated surfaces were avoided during the survey to eliminate the direct influences of roots and direct contact with organic acids (Figure 4A), vegetational influences (including soil formation) appear to have a marked impact on the dissolution rates that have been recorded. In particular, the higher mean dissolution rate on the north-eastern side of the cutting $\left(0.039 \mathrm{~mm} \mathrm{a}^{-1}\right)$ might be explained by the higher concentrations of carbon dioxide derived from the tree stands and soil forming processes and also the higher concentrations of organic acids derived from the same sources. 
Water residence time on surfaces is known to be a significant influence on weathering rates (Trudgill and Viles, 1998). Here, the lower dissolutional rates on the south-western side of the cutting, which is in the shade and therefore subject to higher water residence times, indicate that this is not the prime influence on the rates of dissolution at this locality. Another notable feature of the data is that generally higher rates of dissolution are recorded below the individual chert horizons than above them. This is likely to be attributable to dripping and the prolonged wet periods below the chert, which result from the protection and shade afforded by the protruding chert. On the south-east side of the cutting, in particular, there is evidence of mosses preferentially growing in this location. An additional influence, which has been observed on two (of eight) visits was the presence of at least three species of gastropod on the north-east side of the cutting. Although no attempt has been made to quantify this influence, on one occasion, during wet conditions, it was noted that the gastropods were preferentially situated beneath the chert bands (Figure 4B). The maximum dissolution rates that have been recorded were associated with chert band $\mathrm{i}$ (Figure 2B). This chert band is not associated with an inception horizon or stylolites. Its preferential dissolution supports the hypothesis that some lithologies are prone to greater dissolution than others. Generally higher values were recorded towards the top of the cutting. Whilst this might be attributable to vegetational carbon dioxide and organic acids, consideration should also be given to the potential for sulphur dioxide, derived from the burning of the fossil fuels used to power the trains, to have contributed to the dissolutional processes. Published train emission data is available, e.g. Strategic Rail Authority (2001), but local dispersion modelling would be required to analyse this in detail. Given that sulphur dioxide is denser than air; even though it is emitted with steam there is no evidence to support a significantly higher impact of the sulphur dioxide towards the level of the top of the tunnel. Sulphur dioxide in steam might account for the concentration of higher dissolution rates in the zone 1 to $2 \mathrm{~m}$ to the east of the tunnel on the northern side of the cutting, but this might also be attributable to the greater density of the vegetation in this zone. Furthermore, the influence of train emitted sulphur dioxide was curtailed by the closure of the railway (1959) such that there could not have been any influence from this source during the latter third of the monitoring period.
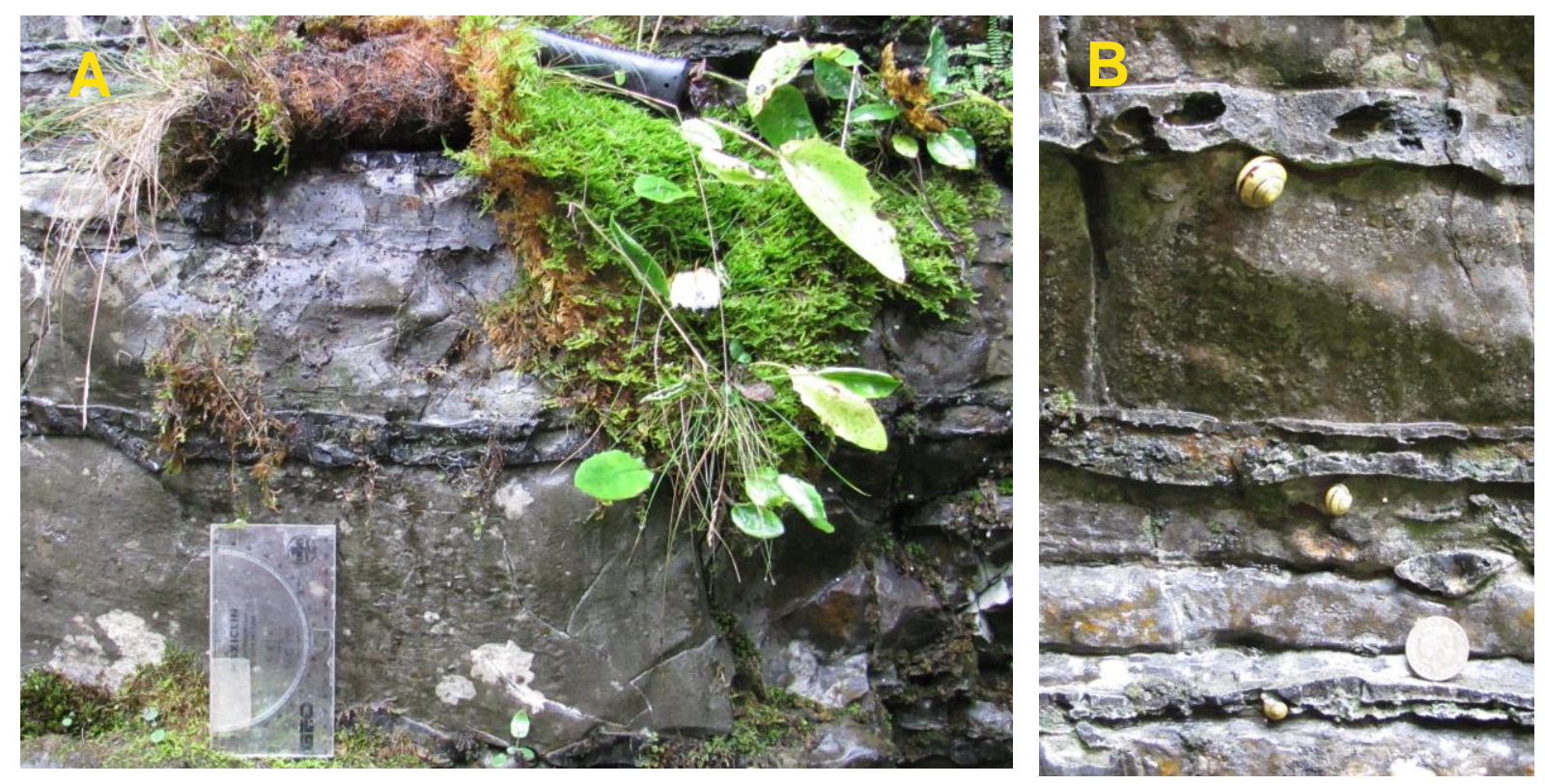

Figure 4. A: limestone surface revealed beneath a vegetated area on the south-western side of the cutting and B: gastropods preferentially situated beneath chert bands on north-east side of cutting. $£ 1.00$ coin (20 $\mathrm{mm}$ ) for scale.

The monitoring results assume that there is negligible dissolution of the chert beds, which based on the relative dissolution rates presented in Table 1 , seems a reasonable assumption. However, any additional erosional processes with respect to the chert also require consideration, because if erosion of the chert is 
demonstrated the results presented here will be an underestimate of dissolution rates. The key weathering process that requires consideration is that of physical and in particular frost weathering. Although very little has been written on the chert of the Peak District the frost susceptibility of flint (chert from the chalk) has been researched, e.g. Lautridou et al. (1986) and Sieveking and Clayton (1986). Lautridou et al. (1986) established that flint is of very low porosity and that, if it contains no cracks, it is not susceptible to frost damage. The presence of the cracks in the cherts above Cressbrook has already been noted. These are likely to result from a number of stress changes, but in particular: the stress field at the time of formation of the chert, the subsequent tectonic history, additional loading imposed by glaciations and any subsequent blasting of the limestone. Close examination of the nodular chert reveals flaking in a pseudo-spherulitic form at the boundary between the chert and the limestone (Figure 2, A and B). It is suspected that this is a periglacial feature. It is plausible that it is a consequence of frost susceptibility focused on pre-existing cryptic cracks and associated with the increased porosity at the contact between the chert and the limestone. Similar increases in porosity have been observed in flint (Sieveking and Clayton, 1986). The association of inception horizons with stylolites suggests a ready supply of moisture that might increase the frost susceptibility of the chert. The localised scale of the flaking suggests that it is unlikely to have significantly distorted the measurements of the protrusion of the chert relative to the limestone.

\section{Rates of surface lowering.}

Trudgill and Viles (1998, p. 333) noted that field observations of geomorphological process are realistic but may be uncontrolled and site-specific. The aim of this study was to provide bulk denudation rates adjacent to the tunnel portal rather than facilitate discrimination between the differing agents of weathering, i.e. chemical, biological and physical, albeit that some interesting observations have been made in this respect. Accordingly, the representativeness of the results must also be considered. Firstly, there is the influence of the sub-vertical surfaces, which may facilitate higher surface flow velocities with a greater potential for dissolution, albeit that the residence time will be less; and may minimise the potential for ponding, thereby reducing residence time compared with plateau settings. Secondly the former rail cutting intercepts vadose zone inception horizon-related flow paths, which will result in locally higher residence times whilst the supply of recharge water is maintained; and potentially facilitates mixing of surface and groundwater at the point at which any groundwater emanates from the rock face. At this point there is a greater potential for dissolution as a consequence of water mixing (Bogli, 1964), although this is not evident in the results presented here.

Table 7: Denudation rates.

\begin{tabular}{|l|l|l|}
\hline Location & $\begin{array}{l}\text { Denudation Rate } \\
\left(\mathbf{m m ~ a ~}^{-1} \text { ) }\right.\end{array}$ & Reference \\
\hline Yorkshire & 0.051 & Goodchild, 1875 \\
\hline Yorkshire & 0.042 & Sweeting, 1966 \\
\hline NW Yorkshire & $0.049-0.050$ & Sweeting, 1972 \\
\hline Yorkshire & $0.003-0.013$ & Goldie, 2006 \\
\hline $\begin{array}{l}\text { Yorkshire } \\
\text { (Post Devensian) }\end{array}$ & $0.0037-0.0135$ & Parry, 2007 \\
\hline Yorkshire & 0.018 & Wilson et al., 2012 \\
\hline Derbyshire & 0.083 & Pitty, 1966 \\
\hline Derbyshire & $0.055-0.100$ & Piggott, 1962 \\
\hline Slovenia & $0.077-0.080$ & Gams, 1962 \\
\hline North Norway & $0.033+/-0.010$ & Lauritzen, 1990 \\
\hline
\end{tabular}

Rates of dissolution cited by others (expressed below as $\mathrm{mm} \mathrm{a}^{-1}$; Table 7) have been compared with the results of this monitoring. An early measurement of dissolution rates was made by Goodchild (1875) who determined a rate of one inch per 500 years $\left(0.051 \mathrm{~mm} \mathrm{a}^{-1}\right)$ from the relative dissolution of limestone and its fossils dated 
on gravestones in St Stephens Church, Kirby Stephen, Yorkshire. Dissolution rates of $0.083 \mathrm{~mm} \mathrm{a}^{-1}$ have been quoted for Derbyshire and Yorkshire (with $0 \%$ and $50 \%$ respectively being derived from underground sources; Pitty, 1966 and Sweeting, 1966). Any assumption of $100 \%$ surface lowering is likely to be in error. More recent developments in the understanding of carbonate dissolution, in particular that of kinetic thresholds and the importance of flow convergence, suggest that an underground component should be expected in all environments. Other published rates include Piggott (1962) $0.055-0.100 \mathrm{~mm} \mathrm{a}^{-1}$ in Derbyshire; Sweeting (1972) $0.049-0.050 \mathrm{~mm} \mathrm{a}^{-1}$ for north-west Yorkshire, and Gams (1962) 0.077-0.080 $\mathrm{mm} \mathrm{a}^{-1}$ for Slovenia and Lauritzen (1990) $0.0325+/-0.0102 \mathrm{~mm} \mathrm{a}^{-1}$ in North Norway. Using pedestals at Norber, North Yorkshire, Parry (2007) determined post Devensian sub-regolith surface lowering rates of $0.046 \mathrm{~mm} \mathrm{a}^{-1}$, whereas Goldie (2006) determined rates of 0.003 to $0.013 \mathrm{~mm} \mathrm{a}$. More recently, Wilson et al. (2012) used cosmogenic ${ }^{36} \mathrm{Cl}$ dating to obtain a mean erratic age of 17.9 +/- 1.0 ka at Moughton, North-West England, based on the analysis of four samples and based on their assessment of mean surface lowering being $33 \mathrm{~cm}$, the estimated the rate of surface lowering is $0.018 \mathrm{~mm} \mathrm{a}^{-1}$. The latter assumes continuous surface lowering, whereas in reality the rates are likely to fluctuate with climatic conditions. Smith and Atkinson (1976) determined a regression line of Dn $(\mathrm{mm} / \mathrm{ka})=0.0552(\mathrm{P}-\mathrm{E} \mathrm{mm} / \mathrm{a})+7.93$ for temperate regions. For this part of the Peak District based on an effective rainfall of $680 \mathrm{~mm}$ (Banks 2007 for the period 2001 to 2003) this equates to $0.045 \mathrm{~mm} \mathrm{a}^{-1}$, which is very close to the value determined for north-west Yorkshire by Sweeting (1972).

The new results reported in this paper (mean of $0.035 \mathrm{~mm} \mathrm{a}^{-1}$ ) lie towards the lower end of the range of rates that have been cited for temperate climates. This may be a consequence of a number of factors, including the fact that the cutting faces are subvertical, the short duration of exposure and the relative amelioration of the climate during the late Flandrian. However, it may also reflect the position of the research site in the landscape or be the consequence of atmospheric changes, in particular the decrease in the atmospheric sulphur content that contributes to acid rain, e.g. Coulson et al. (2005). The dissolution rates determined in this study are probably most representative of valley side locations. They fall between the lower values determined for plateau surfaces (Goldie, 2006) and the solute concentration/ mass balance studies (e.g. Pitty, 1996 and Trudgill, 1985a), which incorporate the higher values of dissolution associated with hydrological focusing on valley floors. Within the context of the railway cutting the exposure of a profile of the limestone to the elements will result in a greater potential for dissolution to be initiated over the entire face.

Surface lowering rates that have been determined are generally lower than the regional uplift rates that have been determined over a range of time periods, e.g. 30-60 mm/ka post late-Pliocene (Pound et al., 2012), and $55 \mathrm{~mm} / \mathrm{ka}$ for the Quaternary (Banks et al., 2012). Where uplift exceeds dissolution subterranean dissolution will be facilitated as groundwater recharge is focused on the local base-level. In the context of landscape evolution limestone dissolution rates are directly proportional to the rate of run-off and are enhanced in the presence of vegetation, whereas the surrounding silicate rocks are largely removed by physical erosion, which is a relatively high energy, seasonal process that is inhibited by vegetation growth (Simms, 2004).

\section{Conclusions regarding methodology, rates of dissolution and implications for other areas}

A mean dissolutional lowering rate of $0.033 \mathrm{~mm} \mathrm{a}^{-1}$ has been determined from the systematic measurement of differential dissolution between limestone and chert adjacent to the south-eastern end of the Cressbrook tunnel. Mean rates of dissolutional lowering ranged between $0.039 \mathrm{~mm} \mathrm{a}^{-1}$ on the north-eastern side of the cutting and $0.031 \mathrm{~mm} \mathrm{a}^{-1}$ on the south-western side. The results presented here have been limited to surface dissolution, but denudation in carbonate terrains occurs both at the surface and within the rock mass, indicating that the results are representative of a specific time period (the last 129 years), but much longer term values would need to take account of the potential for surface collapse and consequential lowering brought about by the instability resulting from dissolution within the bedrock. It follows that this technique could be used to support assessments of the proportion of surface to subsurface dissolution in catchments where mass balance of solutes in drainage basins is being monitored. Such a study could be undertaken at this 
study site; it would require collection and analysis of surface water and inception horizon-related discharge from the seepages emanating from the cutting faces.

In the context of the published literature, the results presented here appear to be representative of valley side surface lowering rates in temperate climates. There is potential for extending the application of the technique to buildings and walls, e.g. churches and other notable buildings that incorporate dressed inter-bedded limestone and chert that can be dated. This would be useful both for considering recent dissolution rates in steeper components of the landscape and the durability of the building stones being measured. Whilst this technique appears to have been reasonably successful the data is spatially discontinuous and reliant on averaging. A more accurate technique would be to undertake ground based LiDar monitoring of the surfaces of interest in order to determine volumetric rates of change.

Whilst the aims of this research were to derive broad rates of limestone dissolution (over the last 129 years), the cutting has provided an excellent opportunity to test the influence of aspect on rates of limestone dissolution. The findings of this study support the hypothesis that carbon dioxide is the single most important factor in limestone dissolution. The evidence comes from the higher dissolution rates measured on the northeast side of the cutting, which supports a higher density of semi-mature trees and vegetation (grass and moss) on ledges than the south-west side. The data suggest that aspect is also important (Ford and Williams, 2007), but in this study this cannot be numerically separated and is not mutually exclusive of vegetational influences and associated carbon dioxide inputs. Ground and surface water mixing has not proved to be as significant as anticipated. It is suspected that this is because the vadose zone flow paths are relatively shallow and have limited contact with the bedrock such that groundwater bedrock interactions are immature.

The site lends itself to further study, in particular, to determine the relative contributions of the chemical, physical and biological controls on rate of dissolution. Strategic sampling of the rock face could be undertaken to facilitate petrological examination of the limestone face with a view assessing the evidence for organic acid smoothing and lithological influences. To test the relative significance of limestone density on the dissolution rates it would be useful to take some cored samples for density determinations and to make comparison with laboratory derived rates of dissolution (Franke and Teschner-Steinhardt, 1994; Trudgill and Viles, 1998).

Acknowledgements: We thank Dr Murray Lark for useful discussion regarding the statistical analyses This paper is published with permission of the Executive Director, British Geological Survey (NERC). Two anonymous referees are thanked for their constructive comments on an earlier version of the text, which has resulted in significant improvements to the text.

\section{References:}

Aitkenhead, N., Chisholm, J.I. and Stevenson, I.P. 1985. Geology of the country around Buxton, Leek and Bakewell. British Geological Survey. HMSO. 168pp.

Appelo, C.A.J. and Postma, D. 2005. Geochemistry, groundwater and pollution. $2^{\text {nd }}$ edition. 649pp. A.A. Balkema Publishers.

Atkinson, T.C. 1977. Carbon dioxide in the atmosphere of the unsaturated zone: an important control of groundwater hardness in limestones. Journal of Hydrology, 35, 111-123.

Balco, G. and Shuster, D.L. 2009. Production rate of cosmogenic Ne-21 in quartz estimated from Be-10, Al-26 and Ne-21 concentrations in slowly eroding Antarctic bedrock surfaces. Earth and Planetary Science Letters 281, pp. 48-58. 
Banks, V.J. 2007. Karst hydrogeology of the southern catchment of the River Wye, Derbyshire. Unpublished PhD thesis, University of Huddersfield.

Banks, V.J., Jones, P.F., Lowe, D.J., Lee, J.R., Rushton, J. and Ellis, M.A. 2012. Review of tufa deposition and palaeohydrological conditions in the White Peak, Derbyshire, UK: implications for Quaternary landscape evolution. Proceedings of the Geologists' Association 123, 117-129.

Banks, V.J., Gunn, J. and Lowe, D.J. 2009. Stratigraphical influences on the limestone hydrogeology of the Wye catchment, Derbyshire. Quarterly Journal of Engineering Geology and Hydrogeology 42, 211-225.

Beck, J.S. 1980. Aspects of speleogenesis in the Carboniferous Limestone of North Derbyshire. Unpublished PhD. Thesis. University of Leicester. 336pp.

Bogli, A. 1964. Mischungskorrosion: ein Beitrag zum Verksrstungsproblem. Erdkunde, 18, 2, 83-92.

Bowering, G. and Flindall, R. 1998. Hard Times. Reprinted from Mining History the Bulletin of the Peak District Mines Historical Society, 13, No.5, Summer 1998. 31pp.

British Geological Survey. 1978. Buxton England and Wales Sheet 111. Solid and Drift Edition. 1: 50000 Series. NERC.

Colman, T.B., Jones, D.G., Plant, J.A. and Smith, K. 1989. Metallogenic models. In: Plant, J.A and Jones, D.G., (Editors). 1989. Metallogenic models and exploration criteria for buried carbonate-hosted ore deposits - a multidisciplinary study in eastern England. London: The Institution of Mining and Metallurgy, Keyworth, Nottinghamshire: British Geological Survey, 123-133.

Corbel, J. 1960. Erosion en terraine calcaire: vitesse d'erosion et morphologie, Annals of Geography 66, 97120.

Coulson, J.P., Bottrell, S.H. and Lee, J.A. 2005. Recreating atmospheric sulphur deposition histories from peat stratigraphy: Diagenetic conditions required for signal preservation and reconstruction of past sulphur deposition in the Derbyshire Peak District, UK. Chemical Geology, 218, 223-248.

Cox, F. C. and Bridge, D. McC. 1977. The limestone and dolomite resources of the country around Monyash, Derbyshire. Mineral Assessment Report Institute of Geological Sciences, 26.

Crabtree, R.W. and Trudgill, S.T. 1985. Chemical denudation of a Magnesian Limestone hillslope, field evidence and implications for modelling. Earth Surface Processes and Landforms, 10, 331-341.

Downing, R.A., Land, D.H., Lovelock, P.E.R., Allender, R. and Bridge, L.R. 1970. The Hydrogeology of the Trent River Basin. Hydrogeological Report No. 5. Water Supply Papers of the Institute of Geological Sciences. 101pp. Reprinted 1971.

Drew, D. 1985. Karst processes and landforms. Aspects of Geography (Series Editors Clayton, K. and Johnson, J.H.). 63 pp.

Fleurant, C., Tucker, G.E. and Viles, H.A. 2008. A model of cockpit karst landscape, Jamaica. Géomorphologie: relief, processus, environnement, 3-14.

Fookes, P.G., Gourley, C.S. and Ohikere, C. 1988. Rock weathering in engineering time. Quarterly Journal of Engineering Geology and Hydrogeology, 21, 33-57.

Ford, D and Williams, P. 1989. Karst Geomorphology and Hydrogeology. John Wiley and Sons Limited. 601 pp.

Ford, D and Williams, P. 2007. Karst Hydrogeology and Geomorphology. John Wiley and Sons Limited. 562 pp.

Ford, T.D. 2002. Rocks and Scenery of the Peak District. Landmark Publishing. 96 pp.

Ford, T.D. and Cullingford, C.H.D. (Editors). 1976. The science of speleology, Academic Press. 593 pp. 
Franke, W.A. and Teschner-Steinhardt, R. 1994. An experimental approach to the sequence of the stability of rock-forming minerals towards chemical weathering. Catena, 21, 279-290.

Gabrovsंek., F. 2007. On denudation rates in karst. Time in Karst Conference, Postojna, 2007, 7-13.

Gams, I., 1962. Measurements of corrosion intensity in Slovenia and their geomorphological significance, Geogr. Vestnik Ljubljana, 34, 3-20.

Garrels, R.M. and Mackenzie, F.T. 1971. Evolution of sedimentary rocks: New York, W.W. Norton. 397pp.

Gawthorpe, R.L., Gutteridge, P. and Leeder, M.R. 1989. Late Devonian and Dinantian basin evolution in northern England and North Wales. In Arthurton, R.S., Gutteridge, P. and Nolan, S.C. Eds. The role of Tectonics in Devonian and Carboniferous sedimentation in the British Isles. Yorkshire Geological Society Occasional Publication, 6, pp. 1-23.

Goldie, H.S. 2006. Mature intermediate-scale surface karst landforms in NW England and their relations to glacial erosion. In A. Kiss and Mezõsi, G. and S. Z. (Eds) Taj. Komyezet es tarsadalom (Landscape, Environment and Society. Studies in Honour of Professor Ilona Bárány-kevei on the occasion of her Birthday), Hungary: Szeged. 225-237.

Goodchild, J.G. 1875. Glacial Erosion. Geological Magazine, 323-328.

Goodchild, J.G. 1890. Notes on some observed rates of weathering of limestones. Geological Magazine, 7, 10, 463-468.

Gunn, J. 1986. Solute processes and karst landforms. In Solute Processes. Ed. Trudgill, S.T. John Wiley and Sons Ltd. pp. 363-437.

Halpin, S. 2004. The geochemistry of chert in the Peak District. Unpublished undergraduate project, Division of Geographical Sciences, University of Huddersfield. 51pp.

Harrison, D.J. and Adlam, K.A. McL. 1985. A guide to the limestone and dolomite resources of the Peak District of Derbyshire and Staffordshire. Description of parts of 1: 50000 geological sheets 99, 111, 112, 124 and 125. Mineral Assessment Report 144. HMSO. 45pp.

Hem, J.D. 1985. Study and Interpretation of the chemical characteristics of natural water. $3^{\text {rd }}$ edition. US Geological Survey Water Supply Paper 2254.

Herman, J.S. and White, W.B. 1985. Dissolution kinetics of dolomite: Effects of lithology and fluid flow velocity. Geochimica et Cosmochimica Acta. 49, 2017-2026.

Hesse, R. 1988. Diagenesis 13. Origin of Chert: Diagenesis of biogenic siliceous sediments. Geoscience Canada, 15, No.3, pp 171-192.

Hesse, R. 1989. Silica diagenesis: Origin of Inorganic and Replacement Cherts. Earth Science Reviews, 26, 253284.

Hey, D. 2008. Derbyshire a history. Carnegie Publishing Limited. 482 pp.

High, C. and Hanna, F.K. 1970. A method for the direct measurement of erosion on rock surfaces. British Geomorphological Research Group Technical Bulletin, no 5, 24 pp.

Hollis, C. and Walkden, G. 1996. The use of burial diagenetic calcite cements to determine the controls upon hydrocarbon emplacement and mineralization on a carbonate platform, Derbyshire, England. In: Strogen, P., Somerville, I.D., and Jones, G.L (Eds). Recent Advances in Lower Carboniferous Geology. Geological Society Special Publication, 107, 35-49.

Jessop, P. 1931. Agate and the cherts of Derbyshire. Proceedings of the Geologists' Association, 42, 29-53. 
Kaufmann, G. and Dreybrodt, W. 2007. Calcite dissolution kinetics in the system CaCO3-H20-CO2 at high undersaturation. Geochimica et Cosmochimica Acta, 71, 1398-1410.

Kehew, A.E. 2001. Applied chemical hydrogeology. Prentice Hall.368pp.

Lautridou, J.P., Letavernier, G., Lindé, K., Etlicher, B. and Ozouf, J.C. 1986. Porosity and frost susceptibility of flints and chalk: laboratory experiments, comparison of 'glacial' and 'periglacial' surface texture of flint materials, and field investigations. In Sieveking, G de G. and Hart, M. B. The Scientific Study of Flint and Chert. Cambridge University Press, pp 43-54.

Lauritzen, S-E. 1990. Autogenic and allogenic denudation in carbonate karst by the multiple basin method: an example from Svartisen, North Norway. Earth Surface Processes and Landforms, 15, 157-167.

Lowe, D.J. 2000. Role of stratigraphic elements in speleogenesis: the speleoinception concept. In: Speleogenesis evolution of karst aquifers. Eds. Klimchouk, A.B., Ford, D.C., Palmer, A.N. and Dreybrodt, W. pp. 65-76.

Martinez, M.I. and White, W.B. 1999. A laboratory investigation of the relative dissolution rates of the Lirio Limestone and the Isla de Mona dolomite and implications for cave and karst development on Isla de Mona. Journal of Cave and Karst Studies, 61 (1), 7-12. April 1999.

Meybeck, M. 1987. Global chemical weathering of surficial rocks estimated from river dissolved loads. American Journal of Science, 287, 401-428.

Mcllroy de la Rosa, J.P., Warke, P.A. and Smith, B. 2013. Lichen induced biomodification of calcareous surfaces: Bioprotection versus biodeterioration. Progress in Physical Geography doi:10.1177/0309133312467660.

Orme, G.R. and Ford, T.D. 1970. Polyphase mineralization in chert from the Ashford Black Marble Mine, Derbyshire. Proceedings of the Yorkshire Geological Society, 38, 163-173.

Parry, B. 2007. Pedestal formation and surface lowering in the Carboniferous Limestone of Norber and Scales Moor, Yorkshire, UK. Cave and Karst Science, 34, 2, 61-68.

Pigott, C.D. 1962. Soil formation and development on the Carboniferous Limestones of Derbyshire: parent materials. Journal of Ecology, 50, 145-156.

Pitty, A.F. 1966. An approach to the study of karst water, University of Hull Occasional Paper, Geography No 5.

Pope, G.A., Meierding, T.C. and Paradise, T.R. 2002. Geomorphology's role in the study of weathering of cultural stone. Geomorphology 47, 211-225.

Pound, M.J., Riding, J.B. Donders, T.H. and Daskova, J. 2012. The palynostratigraphy of the Brassington Formation (Upper Miocene) of the southern Pennines, central England. Palynology, DOI:10.1080/01916122.2011.643066.

Rieuwerts, J.H. 2008. Lead Mining in Derbyshire: history, development and drainage. 2. Millers Dale to Alport and Dovedale. Landmark Collectors Library $142 \mathrm{pp}$.

Sieveking, G de G. and Clayton, C.J., 1986. Frost shatter and the structure of frozen flint. In: Sieveking, G de G. and Hart, M. B. The Scientific Study of Flint and Chert. Cambridge University Press, pp 43-54.

Simms, M. 2004. Tortoises and hares: dissolution, erosion, isostasy in landscape evolution. Earth Surface Processes and Landforms, 29, Issue 4, 477-494.

Smith, D.I. and Atkinson, T.C. 1976. Process, landforms and climate in limestone regions, 367-409. In: Derbyshire, E. Ed. Geomorphology and Climate, 512pp.

Stanton, W.I. 1986. Snail holes (heixigenic cavities) in hard limestone and aid to the interpretation of karst landforms. Proceeding of the University of Bristol Speleological Society 17, 3, 218-228. 
Strategic Rail Authority, November 2001. Rail Emission Model. AEA Technology Report. 24 pp.

Sweeting, M.M. 1972. Karst Landforms. Macmillan. 362 pp.

Sweeting, M.M. 1966. The weathering of limestones, Essays in Geomorphology, 117-210, Heinemann, London, 1966.

Terjesen, S.G., Egra, O., Thoresen, G. and Ve, A. 1961. Phase boundary processes as rate determining steps in reactions between solids and liquids. The inhibitory action of metal ions on the formation of calcium bicarbonate by the reaction of calcite with aqueous carbon dioxide. Chemical Engineering Science, 14, 277289.

Trudgill, S.T. 1983. Weathering and Erosion. Sources and Methods in Geography Series. Butterworths. 192 pp.

Trudgill, S.T. 1985a. Field observations of limestone weathering and erosion in the Malham District, North Yorkshire. Field Studies 6, 201-236.

Trudgill, S.T. 1985b. Limestone geomorphology. Longman. 196pp.

Trudgill, S.T. and Viles, H.A. 1998. Field and laboratory approaches to limestone weathering. Quarterly Journal of Engineering Geology 31, 333-341.

Trudgill, S.T. 2008. Corbel, J. 1959: Erosion en terrain calcaire (vitesse d'érosion et morphologie) Annales de Géographie 68, 97-120. Progress in Physical Geography 32, 6, 684-690.

Walkden, G.M. 1987. Sedimentary and diagenetic styles in Late Dinantian Carbonates of Britain. In: European Dinantian Environments. Edited by Miller, J., Adams, A.E. and Wright, V.P. pp. 131-155.

White, W.B. 1984. Rate processes: chemical kinetics and karst landform development: In: La Fleur (Eds) Groundwater as a geomorphic agent, Allen and Unwin, 227-248.

White, W.B. 2000. Dissolution of limestone from field observations. In: Klimchouk, A.B., Ford, D. C., Palmer, A.N. and Dreybrodt, W. (Editors) Speleogenesis: evolution of karst aquifers, 149-155.

Wilson, P., Barrows, T.T., Lord, T.C. and Vincent, P.J. 2012. Surface lowering of limestone pavement as determined by cosmogenic $\left({ }^{36} \mathrm{Cl}\right)$ analysis. Earth Surface Processes and Landforms, 37, 1518-1526. 